\title{
Values of Novel 99 Lights in the European Sky by Hanum Salsabiela and Rangga Almahera
}

\author{
Rianawati $1^{1, a^{*}}$ and Nurasmah ${ }^{1, b}$ \\ ${ }^{1}$ Faculty of Tarbiyah and Educational Science, State Islamic Institute of Pontianak, Letjend Suprapto Street, Benua Melayu Darat, Pontianak City of West \\ Kalimantan \\ a irin_ptk@ymail.com; bnurnurasmah@yahoo.com \\ ${ }^{*}$ Corresponding Author \\ Whatsapp number: [082148263025]
}

How to Cite : Rianawati, R., Nurasmah, N. (2020). Values of Novel 99 Lights in the European Sky by Hanum Salsabiela and Rangga Almahera. International Journal for Educational and Vocational Studies, 2 (1), 121-127. DOI: https://doi.org/10.29103/ijevs.v2i1.2089

\section{ARTICLE HISTORY}

Received:3 October 2019

Revised: 23 November 2019

Accepted: 6 January 2020

\section{KEYWORDS}

\section{Novels;}

Moral Values;

God Almighty;

Self;

Fellow Human Beings;

\begin{abstract}
This study is motivated by moral learning which sometimes makes students bored. Text books or modules that contain moral lessons, make students lazy to read them. Students only get knowledge about the morals of learning through textbooks, modules, from information conveyed by the teacher. Students also do not know the meaning, do not appreciate, and do not know how to apply morals in real life everyday. Moral learning in schools is only normative and dogmatic in nature, so teachers only pay attention to the cognitive aspects, while the psychomotor and affective aspects receive less attention. Novels are one source of moral learning. This is because the figures and settings in the novel can be used as examples and guidelines for students in living moral lives in society. The focus of this research is: Moral values in the novel 99 Cahaya di Langit Eropa by Hanum Salsabiela and Rangga Almahendra. To answer the focus of the research, the research questions are; 1). How do the values of human morals towards Allah SWT in the novel 99 Cahaya di Langit Eropa by Hanum Salsabiela and Rangga Almahendra.2). How do the values of human morals towards themselves, 3). How do the moral values of humans towards fellow humans in the novel 99 Cahaya di Langit Eropa by Hanum Salsabiela and Rangga Almahendra. 3). How do the moral values of humans against fellow Muslims. The purpose of this study is to describe and analyze the moral values in the novel 99 Cahaya di Langit Eropa by Hanum Salsabiela and Rangga Almahendra. This research method is qualitative. This is because the object and source of this research is the text of the novel 99 Cahaya di Langit Eropa by Hanum Salsabiela and Rangga Almahendra. Researchers become a key instrument because researchers who read critically the text of the novel. After reading intensively and critically, researchers describe, interpret, and analyze data to answer the focus of the research problem. The data in the form of words, sentences, and paragraphs. In analyzing the data, researchers used the hermeneutic technique. The results of the analysis in this study indicate that the novel 99 Cahaya di Langit Eropa is an Islamic novel that contains moral values. Moral values contained in the novel 99 Cahaya di Langit Eropa are moral values towards Allah SWT are worship prayers, fasting and reading the Qur'an. Moral values to yourself are honesty, patience, and sincerity. Moral values towards fellow human beings are tolerance and helping. While the moral values of fellow Muslims are greeting, fulfilling invitations, and advising each other.
\end{abstract}

This is an open access article under the CC-BY-SA license.

\section{INTRODUCTION}

Based on Law No. 20/2003 concerning to national education which functions to develop capabilities and shape the dignified character and civilization of the nation in the context of educating the nation's life, aims to develop the potential of learners to become human beings who believe in and have faith in God Almighty, have good morals, healthy, knowledgeable, capable, creative, independent, and become democratic and responsible citizens. To achieve these goals, one of the fields of study that must be studied by students in madrasah is Moral Education, which is to form students into human beings of faith and devotion to God Almighty and have good character. The basic framework of Islamic teachings includes three main study concepts, namely aqeedah, sharia, and morals. Morals are the fruit that results from the process of applying aqidah and sharia. Like a building, morals are the perfection of the building after the foundation and building are well built. 
Impossible akhlakul karimah (good aqidah) will manifest in a person if he does not have good aqeedah and sharia.

Moral occupies a very important position in Islam, so every aspect of Islamic teachings is always oriented to the formation of noble morals. But in reality there is a moral deterioration among children and even parents. The problem of this nation is only on moral issues, education in Indonesia mostly only revolves around cognitive knowledge, while the morality is not so well paid attention. The failure of moral education, because of unclear goals. The main goal in moral education is the formation of noble morals.

Moral education in schools until now still has many shortcomings. Deficiencies as an impact of educational practices that ignore the awareness of religious values, affective, conative-collative (Rianawati 2014, 375). Sofyan Sauri and Nurdin $(2008,19)$ explain that the problem of deterioration in values, morals and morals is a very important national problem, this decline cannot be separated from the ineffectiveness of instilling moral values both in the family, school and community as a whole, so that the effectiveness of education the value that goes on at the level of formal education is still being questioned, including moral education. Whereas moral subjects should not only lead students to master moral theories, but the most important is how students apply moral theories. Moral subjects emphasize wholeness and cohesiveness between the cognitive, psychomotor and affective domains (Dirjen Dikdasmen 2003, 2).

Based on this assumption, moral learning must be arranged in such a way as to produce a good product. A good product is not just knowledge but also application in the field is also good. Moral education for teenage students is very important and not easy, especially for students who lack guidance and inadequate moral education. For example those who come from families who pay less attention to morals or differences in opinion between father and mother regarding the criteria of good and bad morals. Furthermore, Nata $(2000,45)$ argues, the problem of the failure of the education world so far is only fostering intelligence, intellectual and skills alone without being balanced with emotional intelligence education.

Weaknesses that are owned by schools due to the emergence of gaps in implementing the Islamic education (PAI) curriculum are the limitations of all aspects of the curriculum so that compliance with one particular sector of this limitation cannot overcome the problem as a whole, because it collides with other aspects. Atho 'Mudzhar (Tempo, 24 November 2004) in Muhaimin 2005, 25-26) stated the results of the Religious Research and Training of Religion in 2000, that "the decline in morals and morals of students caused by, among others, due to the religious curriculum that was too dense material and the material emphasizes aspects of thinking rather than building religious awareness. In addition, the method of religious education does not encourage the sentiment of religious values and the limitation of religious reading materials. The current religious education package books are inadequate to build religious awareness, provide religious functional skills and encourage moral and moral behavior in students. In the context of the methodology, the results of Furchan's research (1993) (Muhaimin 2005, 26) also show that "The use of PAI learning methods in schools mostly still uses traditional learning methods, namely monotonous lectures and contextual static, tend to be normative, monolithic, detached from history and more academic".

Thus it is necessary to find a form of improvement with the right strategy to overcome the overall gap in the implementation of PAI. Habituation to involve children in solving problems is not just training in thinking skills and teaching how to solve problems, but a more substantial goal is to instill understanding to students that there is a good mechanism through question and answer. In the communication process, the teacher sets an example and shows how to learn to listen to the opinions of others. Therefore it is necessary to instill early aspects of awareness in them of the importance of mutual respect for the thoughts of others (Aunurrahman 2010, 13).

The above description can be understood by various criticisms and at the same time the weaknesses of the implementation of religious education lead to aspects of methodology, learning strategies and orientation that are more normative, theoretical and cognitive, including aspects of teachers who are less able to relate and interact with other socio-cultural values. Another aspect that is highlighted is the aspect of curriculum content, educational facilities, the depth of books and educational materials of teaching materials. One strategy in moral learning is strategy in order to attract attention, interest, and fun. Strategies that can be used include stories, especially Islamic stories contained in the novel. The moral code education is obtained directly or indirectly. The direct way can be learned through texts that explicitly explain morals in Islam. While the indirect way is to learn morals from life experiences or absorb moral education values from texts that do not explicitly explain morals. One's spiritual experience to absorb the values of moral education contained therein, according to their respective capacities.

Stories contained in various literary works of art, can stimulate moral development has been used by educators since time immemorial (Musfiroh, et. al. 2005, 23). This means that since long ago stories are believed to be used as a medium for transferring moral values into children. Even a story that actually happened or a true story in the community, will be able to talk more than insistent advice when the child's soul has not been moved (Adhim 2006, 54).

Researcher chooses literary works in the form of novels, because novels present a broader and more complex community life. Novels are in the community because they are formed by community members based on emotional or rational urges in society. Meanwhile, according to Alwi $(2002,788)$ that the novel is interpreted as "a long prose essay, containing a series of stories of a person's life with the people around him by highlighting the character and 
nature of the perpetrators. The language used is more like everyday language Suryaman (Fahmi et. al., 2014, 2) explains that basically literary works contain a lot of usefulness values that can be learned and practiced by the reader. The main function of literature is for refinement, increasing imagination, and increased expression in a creative and constructive manner.

Based on the various opinions above, the type of novel "99 Lights in the Sky of Europe" by Hanum Salsabiela Rais and Rangga Almahendra who are couple husband and wife who were given the task of studying in Austria (Vienna), including popular novels. This is because the novel is a best seller and was filmed on the cinema. One novel that is loaded with Islamic studies and contains the values of Islamic Religious Education is a novel entitled "99 Lights in the Sky of Europe" by Hanum Salsabiela and Rangga Almahendra. This novel has advantages, including: First, this novel has a very interesting storyline, not boring. The storyline of this novel not only tells the traces of Islam in Europe, but also tells the lives of the figures in carrying out Islamic teachings in the midst of a minority Islamic society. The implementation of Islamic teachings in this novel presents how to carry out worship to Allah SWT with various obstacles faced by the characters in the novel.

Noble character must be learned and trained so that it becomes a daily such as rooted and ingrained habit, so that it becomes a habit. Therefore noble morals are needed for education to instill morals. Thus substantially the subjects of morality in schools have contributed in providing motivation to students to learn and practice their creeds in the form of habituation to commendable morals and avoiding despicable morals in everyday life. "Al-akhlaku-karimah" is very important to be practiced and accustomed by students in the lives of individuals, society and nation, especially in order to anticipate the negative impacts of the era of globalization and the multidimensional social crisis that has plagued the nation and State of Indonesia (Depag RI, 2007: 3).

Literary works can be used as a means and medium to convey messages. This is consistent with the opinion of Damono $(1978,3)$ which states that literature is a reflection of society. Thus, literary works can be considered as a tool to describe the life written by the author. Furthermore Sumarjo and Saini $(1997,8-9)$ state that there are some benefits that can be obtained from a literary work, namely: giving awareness to the reader about the truths of life, giving joy and inner satisfaction, giving us a deep appreciation of what is we know, and help the reader become a cultured man. The figures in the literary works can be used as examples and guidelines for humans in living life in society, so that humans return to their nature in accordance with the guidance of religion, especially Islam. A literary work has the main function as refiners of mind, increased sensitivity to humanity, and social care (Martono 2001, 58).

Islamic literary works (novels) circulating in the community are in great demand and are read by students, including novels, poetry, short stories, drama and others. Literary work with a religious or religious theme is urgently needed by students as role models. This is because the first portrayal of the characters in the novel becomes an example and is imitated by students, both in virtue of Allah SWT moral towards humans, and morals towards the environment. This is in line with the opinion of Rene and Waren $(2014,27)$ who say Novelists can teach more about human nature than psychologists. Second, the stories are presented and packaged so interestingly by the author, so students are interested in reading them. Third, the stories in the literary works can also be a source of inspiration and positive encouragement for students to be applied in real life everyday.

Research on religious values, especially Islam contained in literary works has been carried out by Ramlah (2000) with the research title "Religious and Moral Values in the novel Siti Nurbaya by Marah Rusli. The research succeeded in finding religious and moral values related to God, humans, and the natural surroundings. In addition there is also a study conducted by Majid (2011) with the research title The Structure of the Verses of Love and When the Love of Glorification is found in the novel, namely the relationship between man and Allah, human relationship with nature, human relationship with parents, and humans relations. The values contained in the above research in the novel Ayat-Ayat Cinta are trustworthy, the benefits of prayer, sincerity, endeavor, tolerance, and hospitality that can be practiced in daily life. Whereas the novel ketika Cinta Bertasbih has the value of signs of oneness and power of God, blessings for those who work, patiently accepts the test of God, useful knowledge, balance life in the world and in the hereafter.

Other research that also examines the religious values in the novel Dzikir-dzikir Cinta by Anam Khairul Anam by Nuryana (2012) which succeeded in finding moral values towards Allah SWT, which includes giving thanks and blessings to Allah, praying to Allah, making remembrance to Allah Allah, put your trust in Allah, put your trust in Allah and worship Allah. Human morals towards humans in the novel include morals to individuals or oneself (seeking knowledge, patience, honesty, and trust), morals to families, morals to society (ta'awun, deliberation, and preaching).

Comparison for the results of the novel research above, there is a difference between the research on the novel that was done before and the research that was raised by the author. Research by the author will raise the values of morals towards Allah, morals towards fellow human beings, and morals towards fellow Muslims in the novel 99 Cahaya di Langit Eropa. Furthermore, according to researcher the novel has never been studied before into the research.

\section{METHODS}

The approach used in this research is qualitative. According to Satori and Komariah $(2013,24)$ states that qualitative research is designed so that the results of 
research have a contribution to the theory, so that it becomes material for scientists to become materials for the preparation of new theories. Meanwhile, according to Sugiyono $(2011,8)$ states that qualitative research is also called naturalistic research, because the research is carried out in natural conditions. This study uses a qualitative approach because the researcher tries to describe, interpret, and analyze the moral values contained in the novel 99 Cahaya di Langit Eropa by Hanum Salsabiela and Rangga Almahendra.

This type of research is the study of literature or text is a study that focuses on the analysis or interpretation of written materials based on the context. According to Prastowo (2011, 190-191) states that this type of research is carried out in libraries, documents, archives, and the like. For example collecting data in literary research that can be analyzed directly, because literary works are considered as society. The data collected in this study are in the form of phrases, sentences, and even paragraphs in the text of the novel 99 Cahaya di Langit Europe by Hanum Salsabiela and Rangga Almahendra.

The subject of this research is the text of the novel 99 Cahaya di Langit Eropa by Hanum Salsabeila and Rangga Almahendra. P.T. Publisher Gramedia Kota Jakarta The novel was published in July 2011. The total page is 392 , consisting of 52 series with 4 parts of the story. Part I (Vienna) consists of series 1 to 16, page thickness from page 20 to page 123. Part II (Paris) consists of series 17 to 34, page thickness from 124 to page 228. Part III (Cordoba and Granada) consists of series 35 to 45 , with page thickness from 229 to page 313. Part IV (Istanbul) consists of series 46 to 52 , with page thickness from 314 to page 371 . The novel needs to be given meaning so that the meaning literary works can be understood and mastered by the reader (Pradopo 2003, 106).

Research uses documents, then documents or notes are the areas of research or research variables (Suharsimi Arikunto, 2010: 172). Therefore the area of this research is the novel 99 Cahaya di Langit Eropa by Hanum Salsabiela and Rangga Almahendra which are studied as moral values. The moral values examined are morals in relationship with Allah, and human morals with fellow Muslims.

\section{RESULTS AND DISCUSSION}

\subsection{Moral Values Against Allah SWT.}

Worship God, which is carrying out God's commands to worship Him in accordance with His commands. A Muslim worship proves submission and obedience to Allah's commands. Worship in Islam is the culmination of feelings of submission and submission to God and the climax of feelings that feel the greatness of God as a place of self-service. Worship is also a connecting ladder between morals and its creator. Apart from that worship has deep impressions in the corner of the relationship between creature and its creator. Worship in the novel 99 Cahaya di
Langit Europe by Hanum Salsabiela and Rangga Almahendra includes the following elements:

\subsubsection{Shalat / prayer}

Prayers pray to Allah SWT. in the novel 99 Cahaya di Langit Eropa by Hanum Salsabiela and Rangga Almahendra, there is the value of submitting to Allah SWT. The novel depicts Hanum and Fatma figures that use baby and childcare for prayer after German language courses. Even though they did not find a mushalla or mosque, they still performed the important prayer of a clean and unclean place. This is also illustrated by the figure of Rangga who chases Friday prayers, even though he only gets one rak'ah in the mosque, because he is very difficult to carry out Friday prayers. Every Friday prayer time is always about teaching schedules or exams, because on campus they don't know religion or atheism. Rangga's attitude illustrates his obedience to Allah SWT.

This is in accordance with the opinion of Nata (2002, 148) which states human morals to God can be interpreted as attitudes or actions that should be done by humans as creatures to the Creator. Moral to Allah SWT carried out in the form of direct worship such as prayer. Prayers identify obedience, submission to substances that have greatness. The series of readings after the reading is realized and understood its meaning, gradually becoming a moment of cognitive and psychomotor internalisation of monotheism values in people who do it (Fauzan 2017, 62).

\subsubsection{Fasting}

Fasting is a demand that must be implemented by every Muslim in Ramadhan. However, this fasting is not only during the month of Ramadan, but is also performed in other months such as circumcision fasting such as fasting Monday-Thursday. Fasting will give birth to humans who have strong principles, patience, sincerity and are not unyielding and have solidarity and love one another. This principle seems to fade (even disappear) in some Indonesian people. (Generous 2013, 240)

Novel 99 Cahaya di Langit Eropa by Hanum Salsabiela and Rangga Almahendra tells the Monday-Thursday fasting service conducted by Fatma. Rangga also fasts during Ramadan. The Fatma figure who runs the Monday-Thursday fast is the beginning of his introduction to Hanum. Hanum understood that Fatma was fasting Monday-Thursday, so Fatma knew that Hanum was a Muslim.

\subsubsection{Reciting Al-Qur'an}

Reading the Koran in the novel 99 Cahaya di Langit Eropa by Hanum Salsabiela and Rangga Almahendra is depicted in the character Fatma and her friends gather to read and study the Koran. They read and at the same time study the Koran at Fatma's house. In reading the Koran they help one another and the tutor is Fatma. The Qur'an contains complex and comprehensive values of Islamic education. 
Besides reading the Qur'an will develop the character of enterprising, diligent, disciplined, patient, patient, istiqomah, and concentration (Judge 2018, 2).

\subsection{Moral Values of Self}

\subsubsection{Honest}

An honest attitude in the novel 99 Cahaya di Langit Eropa by Hanum Salsabiela and Rangga Almahendra illustrated Hanum's attitude to take the newspaper without paying first. Hanum was not unwilling to pay, but it just so happened that he didn't have a coin to put in the place that had been prepared. But he promised the next day he would pay. Even if Hanum did not pay for the newspaper it would not be discovered, but he was sure that Allah Almighty knew what he was doing. Therefore he was afraid not to pay for the newspaper.

An honest attitude will lead people to the morals of Ihsan. With honesty, someone feels afraid to do lies and bad deeds. Imam Al Ghazali divides the nature of honesty or shiddiq in five things, namely honest in words (oral), honest in intention (will), honest in willingness, honest in keeping promises and honest in deeds (amaliah) (Amin 2017, 62)

\subsubsection{Patient}

Patience was also shown by Rangga when he was forbidden to offer prayers in his private room. Rangga felt that he did not disturb people when he prayed because he was in his private room. Finally Rangga succumbed to the rules of the campus to carry out prayers in a place that had been prepared by the campus. A place where all religions practice their worship. The patience of Fatma and Rangga in the novel 99 Light in the Sky of Europe by Hanum Salsabiela and Rangga Almahendra reflects that they have a noble character in themselves. This is because they can control all their anxiety and anxiety in the face of various difficulties that befall them. If they can go through difficult times with patience and trust in Allah SWT, then they will get the pleasure promised by Allah SWT. This is in accordance with the opinion of Qudamah $(2004,343)$ which explains that patience is a shield in holding all trials so as not to be discouraged.

\subsubsection{Helps}

The sincere attitude in the novel 99 Cahaya di Langit Eropa by Hanum Salsabiela and Rangga Almahendra is illustrated by Natalie Deewan's restaurant with the concept of sincerity in paying for food eaten by consumers. He did good deeds only hoping for the pleasure of Allah SWT. This is in accordance with the opinion of Al-Ghazali $(1993,139)$ sincerely interpreted as good deeds which are carried out solely because it expects the pleasure of Allah SWT, because sincerity is the spirit of good deeds.

\subsection{Moral Values Against Humans}

\subsubsection{Tolerance (tasamuh)}

Tasamuh is an attitude that respects and respects others who are different from themselves. Tolerance / tasamuh in the novel 99 Cahaya di Langit Eropa by Hanum Salsabiela and Rangga Almahendra is illustrated by Napoleon's attitude which does not complicate and hinder Muslims in carrying out their worship. The same thing was done by King Roger of Sicily, Italy, which provided space for Muslims to carry out their teachings with the principle of unity in diversity. Tolerance is an attitude that frees a person to carry out his beliefs. (H.M Daud Ali, et al. Arifin 2016 , 398) with the tolerance of the atmosphere of life, someone who is different from other people becomes more harmonious, calm and peaceful.

\subsubsection{Mutual help}

Please help is an attitude that helps each other to lighten the burden of the people we help. Please help in the Cahaya di Langit Eropa by Hanum Salsabiela and Rangga Almahendra depicted figures of Fatma and Hanum who help each other. Fatma helped Hanum to get to know the city of Vienna and Istanbul and Hanum helped Fatma to bring the Vienna newspaper and keep a German certificate. Marion figure who helped Hanum while in Paris. Likewise the Imam of the Le Grande mosque in Paris helped the Jews of the Nazi army. Fatma and Hanum's attitude reflects the attitude of helping please. Please help can be done in various forms, both in the form of material, energy, motivation, morals, and prayer. Abdulah believes in ethical values there is an ethics of helping to help "Ethics Please Help is an attitude that is happy to help others, both in the form of material or energy and morals" (Selfi Maikomah, 2018: 206).

\subsection{Moral Values of Muslims}

\subsubsection{Say greetings}

Saying greetings in the novel 99 Cahaya di Langit Eropa by Hanum Salsabiela and Rangga Almahendra illustrated the attitude of Fatma and Hanum when they met and separated always saying their greetings. Likewise Gomez greets him when he finds out that Hanum and Rangga are Muslims. Greetings that he said as an introduction. Hanum was stuck saying greetings to the veiled woman and it turned out that the woman was non-Muslim, so Hanum's greetings were not answered. This habit is very good if used as a tradition between Muslims. Because by saying hello, someone has prayed for his brother and through greeting someone also tightened the silaturrahim and ukhuwah Islamiyah ropes. This is in accordance with the opinion of Zarkasi $(1987,68)$ stating that prayer in greetings is the salvation of others both soul and body which when expensive. 


\subsubsection{Meet the Invitation}

Meeting the invitation is among the obligations of fellow Muslims. Meeting the invitations in the novel 99 Cahaya di Langit Eropa by Hanum Salsabiela and Rangga Almahendra illustrated Hanum and Rangga fulfilling an invitation to dinner with Fatma's small family. The invitation was in order to introduce each other's husband so that a sense of brotherhood and mutual respect can be established. Likewise, when Hanum was invited to Fatma's house. Hanum's visit was expected by Fatma to introduce her friends and find out where her house was. The purpose of Fatma is to invite Hanum so that Hanum also knows her Fatma friends. Hanum and Rangga always respect and appreciate Fatma by fulfilling the invitation from Hanum. Vice versa, Fatma always respects and appreciates Hanum and Rangga by fulfilling invitations from Hanum and Rangga. Islam is a religion that teaches love, love and brotherhood, one of which is by fulfilling each other's invitations. (Abdullah al-Bassam, tt: 608).

\subsubsection{Advising each other}

Counseling one another in the novel Cahaya di Langit Eropa by Hanum Salsabiela and Rangga Almahendra is depicted by Fatmadan Hanum who are close friends advising each other. Hanum advised Fatma not to despair in finding work and blamed herself. Likewise Fatma's attitude advised Hanum to be a good Muslim agent and a way of responding to the lives of minority Muslims. The two friends advise each other and encourage each other when there is a problem between them or they are getting discouraged.

\section{CONCLUSION}

Moral values towards Allah SWT in the novel 99 Cahaya di Langit Eropa by Hanum Salsabeila and Rangga Almahendra related to the focus of the problem in this study, containing the values of piety, obedience, obedience, and love for Allah SWT. This is illustrated in the novel, first: the determination of Rangga and Hanum in carrying out the prayer, even under conditions of improper place and time, which sometimes clash with the lecture schedule. Secondly, Likewise the fasting that is carried out by Fatma consistently is Monday-Thursday Sunnah fasting, Rangga who carries out Ramadan fasting, even though he must get a trial from his friend. Third, the Worship of reading the Koran illustrates Fatma's attitude which makes her home a place to study and study the Qur'an.

The moral values of oneself in the novel 99 Cahaya di Langit Eropa by Hanum Salsabiela and Rangga Almahendra contain the values of calmness, serenity, happiness and peace that are portrayed in the characters of the novel. First; honestly in the novel illustrated the attitude of Hanum who took the newspaper by paying for himself. A restaurant with the slogan of all you can eat and to pay as much as you can. Likewise, the attitude of Fatma Latife's friends who traded upholds the value of honesty. Second; patience in the novel Fatma's attitude does not reply to ridicule from non-Muslims. Rangga who be patient when prohibited from performing prayers in his private room. Third; sincere in the novel illustrated the attitude of Natalie Deewan who received payment at her restaurant, as sincere as consumers.

Moral values for fellow human beings in the novel 99 Cahaya di Langit Eropa by Hanum Salsabeila and Rangga Almahendra contain values of virtue, brotherhood, role models, and help to be portrayed in the character of the novel. First, tolerance in the novel is illustrated by Napoleon's attitude which gives Muslims space to practice their religion. King Roger in Sicily also gave Muslims the freedom to practice their respective worship. The attitude of tolerance was also carried out by Sultan Ar Rahman when he was in power in Cordoba which made Islam, Christianity, and Judaism coexist. Second, please help in the novel depicted Hanum's attitude to help Fatma because it was ridiculed by non-Muslims and brought the newspaper during a German language course. Marion who helped Hanum to translate the map of Paris. Likewise the mosque's Imam helped the Jews from the pursuit of the Nazi army.

Moral values towards fellow Muslims in the novel 99 Cahaya di Langit Eropa by Hanum Salsabeila and Rangga Almahendra contain the values of love, brotherhood, mutual respect, and goodness depicted in the character of the novel. First; saying greetings in the novel is depicted in the characters Fatma and Hanum who always say hello when meeting and separating. Second; fulfilling invitations in the novel is depicted by Hanum and Rangga figures who meet the invitation of Fatma and her husband, also when Hanum was invited by Fatma to visit her house. Third; mutual counsel in the novel illustrates Hanumyang's attitude to advise Fatma when it was never accepted when applying for work in Vienna. Fatma also advised Hanum to be patient and how to live life while in Vienna and not take newspapers without paying. Rangga advised Hasan to continue his prayers even though he worked in a shop selling pork.

\section{REFERENCES}

Adhim, M. F. (2006). Positive Parenting: Cara-cara Islami Mengembangkan Karakter Positif Pada Anak. Bandung: Mizania.

Al-Bassam \& Abd-Rahman, A. I. (2004). Taudhih al Ahkam min Bulugh al Maram, Jilid III. Kairo: Dar ibn al-Haaitsam.

Alwi. (2002). Kamus Besar Bahasa Indonesia. Jakarta: Balai Pustaka.

Amin, M. (2017). Peran Guru Dalam Menanamkan Nilai Kejujuran pada Lembaga Pendidikan TADBIR. Jurnal Studi Manajemen Pendidikan. 1(1).

Arifin, B. (2016). Implikasi Prinsip Tasamuh (Toleransi) dalam Toleransi Umat Beragama. Jurnal Fikri. 1(2).

Arikunto, S. (2010). Prosedur Penelitian (Suatu Pendekatan 
Praktik). Jakarta: PT. Rineka Cipta.

Aunurrahman. (2010). Belajar dan Pembelajaran. Cet. ke 4. Bandung: Alfabeta

Damono, S. D. (1978). Sosiologi Sastra Sebuah Pengantar Ringkas. Jakarta: Depdikbud.

Dermawan, O. (2013). Pendidikan Karakter Siswa Melalui Ibadah Puasa. Edukasia: Jurnal Penelitian Pendidikan Islam. 8(2).

Fahmi, R. N., dkk. (2014). Analisis Tokoh Utama Dan Nilai Pendidikan Karakter Dalam Novel Anak Sejuta Bintang Karya Akmal Nasery Basral. Basastra Jurnal Penelitian Bahasa, Sastra Indonesia Dan Pengajarannya. 2(3).

Fauzan, A. (2017). Membaca Fenomena Shalat Sebagai Sebuah Tanda (Telaah Kritis Dialektika-Normatif dan Semiotik Tentang Shalat Wajib). Jurnal Dakwah dan Komunikasi. 2(1).

Hakim. (2018). Pendidikan Karakter Melalui Pembelajaran Tahfidz Al-Qur'an Siswa SDIT Al Bina Pangkalpinang. Jurnal JPSD. 5(1).

Maikomah, S. (2018). Analisis Nilai Etika Tolong Menolong Tokoh Hepi Dalam Novel Anak Rantau Karya A Fuadi. Jurnal Ilmiah Dikdaya. 8(1).

Martono. (2001). Sikap Hidup Orang Dayak Keninjal dalam Sastra Lisan Dayak Keninjal yang Terdokumentasikan (Tesis). Pontianak: FKIP Universitas Tanjungpura.

Muhaimin, dkk. (2005). Strategi Belajar Mengajar. Surabaya: Citra Media.

Musfiroh, T., dkk. (2005). Cerita untuk Perkembangan Anak. Yogyakarta: Navila.

Nata, A. (2000). Akhlak Tasauf. Jakarta: Raja Grafindo Persada.

Pradopo, R. D. (2003). Metode Penelitian Sastra. Yogyakarta: Pustaka Pelajar

Prastowo, A. (2011). Metode Penelitian Kualitatif dalam Perspektif Rancangan Penelitian. Yogyakarta: Ar Ruzz Media.

Qadamah, I. (2004). Minhajul Qashidin (Jalan Orang-orang yang Mendapat Petunjuk). Jakarta: Pustaka Al Kausar.

Rianawati. (2014). Implementasi Model Pembelajaran Kontekstual Berbasis Akhlak Kemandirian. Analisis: Jurnal Studi Keislaman. 14(2).

Satori, D., \& Komariah, A. (2013). Metodologi Penelitian Kualitatif. Bandung: Alfabeta.

Sauri, S., \& Nurdin, D. (2008). Pengembangan Model Pendidikan Nilai Berbasis Sekolah, Keluarga, dan Masyarakat. Laporan Hasil Penelitian Hibah Penelitian Tim Pascasarjana (Hibah Pasca). Bandung: Universitas Pendidikan Indonesia.

Sugiyono. (2011). Metode Penelitian Kuantitatif, Kualitatif, dan $R$ \& D. Bandung: Alfabeta.
Sumarjo, J., \& Saini, K.M. (1997). Sekilas Soal Sastra dan Budaya. Jakarta: Balai Pustaka.

Wellek, R., \& Warren, A. (2014). Teori Kesusastraan. Jakarta: PT. Gramedia. 